\title{
PERAN CITRA MEREK MEMEDIASI PENGARUH KEUNGGULAN PRODUK TERHADAP NIAT BELI ULANG PRODUK FASHION UNIQLO
}

\author{
Nyoman Panji Prabawa Sunu' \\ Gede Bayu Rahanatha ${ }^{2}$ \\ ${ }^{1,2}$ Fakultas Ekonomi dan Bisnis, Universitas Udayana, Bali, Indonesia \\ email: panjiprabawasunu@gmail.com
}

\begin{abstract}
ABSTRAK
Tujuan dari penelitian ini adalah untuk menjelaskan dan menganalisis peran citra merek memediasi pengaruh keunggulan produk terhadap niat beli ulang konsumen. Data yang dipergunakan dalam penelitian ini adalah data primer, yaitu dengan melakukan penyebaran kuesioner kepada seluruh responden penelitian yang sudah pernah membeli dan menggunakan produk fashion dari Uniqlo. Populasi dari penelitian ini adalah konsumen yang memakai produk fashion Uniqlo. Berdasarkan perhitungan dengan teknik purposive sampling jumlah sampel yang didapat 110 responden. Teknik analisis yang digunakan dalam penelitian ini adalah uji path analysis, uji sobel dan uji $V A F$. Hasil penelitian ini menunjukkan bahwa, variabel keunggulan produk berpengaruh positif dan signifikan terhadap citra merek begitu juga terhadap niat beli ulang. Variabel citra merek juga berpengaruh positif dan signifikan terhadap niat beli ulang. Variabel citra merek dalam penelitian ini mempengaruhi keunggulan produk dan niat beli ulang secara parsial berpengaruh positif dan signifikan.

Kata Kunci: keunggulan produk, niat beli ulang, citra merek
\end{abstract}

\begin{abstract}
The purpose of this study was to explain and analyze the role of brand image in mediating the effect of product superiority on consumer repurchase intention. The data used in this study are primary data, namely by distributing questionnaires to all research respondents who have bought and used fashion products from Uniqlo. The population of this study are consumers who wear Uniqlo fashion products. Based on calculations with purposive sampling technique, the number of samples obtained is 110 respondents. The analysis technique used in this research is the path analysis test, single test and VAF test. The results of this study indicate that the product superiority variable has a positive and significant effect on brand image as well as repurchase intention. The brand image variable also has a positive and significant effect on repurchase intention. The variable brand image in this study affects product excellence and repurchase intention is partially positive and significant.
\end{abstract}

Keywords: product superiority, repurchase intention, brand image 


\section{PENDAHULUAN}

Di era globalisasi saat ini, produk fashion merupakan salah satu produk yang cukup laris diminati konsumen setelah makanan. Dahulu pakaian atau fashion merupakan kebutuhan primer belaka. Seiring dengan perkembangan industri pakaian, hiburan, teknologi dan informasi, gaya berbusana menjadi media bagi penggunanya untuk bisa menambah rasa percaya diri, terlihat modis dan dapat mendukung gaya hidup. Menurut Fatmawati et al. (2017), fashion atau mode adalah pengaplikasian cara seseorang dalam mengenakan pakaian, aksesoris, atau bahkan dalam bentuk model rambut hingga make up yang dapat dilihat melalui gaya hidup seseorang. Industri fashion adalah salah satu penyumbang terbesar dari 14 industri kreatif di Indonesia. Berdasarkan data survei dari Badan Ekonomi Kreatif (Bekraf) dan Badan Pusat Statistik (BPS), sektor fashion berkontribusi sebanyak $18,15 \%$ atau nomor dua setelah kuliner terhadap total perekonomian nasional tahun 2016. Hal tersebut menunjukkan bahwa, masyarakat Indonesia sudah sangat menyadari untuk berpenampilan menarik dan stylish dengan mengikuti perkembangan tren fashion yang sedang berkembang. Seiring dengan perkembangan bisnis fashion maka, persaingan perusahaan untuk memperoleh keuntungan dan loyalitas konsumen juga semakin meningkat.

Konsumen pada dasarnya merupakan parameter bagi perusahaan untuk tetap bisa berjalan karena, konsumen saat ini sudah lebih teliti dalam memilih produk. Banyak faktor yang menjadi pertimbangan konsumen dalam mengambil keputusan pembelian, seperti inovasi produk dan harga. Pada bidang fashion terdapat banyak merek atau brand yang menjadi pesaing bagi Uniqlo, terutama merek fashion yang berasal dari luar Asia. Uniqlo menjadi merek fashion Asia yang mampu bersaing secara global walaupun masih belum menempati posisi nomor satu di dunia, diferensiasi Uniqlo yang paling unik dibanding pesaingnya yaitu $H \& M$ yang berasal dari Swedia dan Zara yang berasal dari Spanyol dimana juga telah masuk ke pasar Indonesia adalah tidak seperti ritel pakaian lainnya yang menciptakan tren atau menjual produk sesuai tren (fast-cathing fashion trend), Uniqlo tidak mendikte tren pakaian pelanggan, Uniqlo relies on long-term trend. Produk Uniqlo juga menggunakan teknologi airsm dan heat-teach, yang dapat membuat tubuh selalu nyaman dalam kondisi berkeringat sekalipun sehingga, konsumen akan merasakan keunggulan dari produk fashion Uniqlo.

Data yang dirilis oleh Brand Finance pada Tabel 1. menunjukkan bahwa, Uniqlo merupakan merek pakaian yang paling cepat berkembang dalam 10 besar merek pakaian di dunia yang dimana, nilai merek Uniqlo naik sebesar 48,1\% dari tahun 2018 sebesar USD 8,099 menjadi USD 11,991 pada tahun 2019. Uniqlo sebagai perusahaan multinasional akan selalu berusaha untuk mempertahankan eksistensinya diantara pesaing yang ada dengan cara mengembangkan produknya agar dapat diterima dan sesuai dengan keinginan konsumen. Di Indonesia Uniqlo telah membuka 27 gerai yang tersebar di kota-kota besar, salah satunya Bali. Dengan terus berkembangnya gerai Uniqlo di Indonesia membuktikan bahwa, Uniqlo ingin bersaing dengan pesaing-pesaingnya yang memiliki bidang yang sama pada bidang fashion.

Sebuah usaha baru harus melakukan inovasi untuk meningkatkan niat beli ulang pada konsumen. Inovasi produk sangat erat kaitannya dengan keputusan 
pembelian karena inovasi mampu membuat produk berbeda dan memiliki karakteristik di mata konsumen sehingga, akan menambah unsur yang membedakan sebuah produk dengan produk lainnya dan konsumen lebih tertarik membeli kembali produk tersebut. Niat beli ulang merupakan niat pembelian yang didasarkan atas pengalaman pembelian yang telah dilakukan di masa lalu. Niat beli ulang yang tinggi mencerminkan tingkat kepuasan yang tinggi dari konsumen ketika memutuskan untuk mengadopsi suatu produk. Keputusan untuk mengadopsi atau menolak suatu produk timbul setelah konsumen mencoba suatu produk tersebut dan kemudian timbul rasa suka atau tidak suka terhadap produk tersebut. Rasa suka terhadap produk timbul bila konsumen mempunyai persepsi bahwa produk yang mereka gunakan berkualitas baik dan dapat memenuhi atau bahkan melebihi keinginan dan harapan konsumen. Dengan kata lain, produk tersebut memiliki nilai yang tinggi di mata konsumen dan mempunyai sebuah keunggulan di dalam produk tersebut. Tingginya niat beli ulang ini akan membawa dampak yang positif terhadap keberhasilan produk di pasar (Thamrin et al., 2018). Niat beli ulang pasti akan tumbuh pada diri konsumen ketika konsumen merasakan kepuasan dan kenyamanan akan produk yang konsumen beli sebelumnya dan ingin menggunakan kembali. Niat beli ulang merupakan bagian dari perilaku pembelian konsumen dimana kesesuaian antara performa dari produk atau jasa yang ditawarkan perusahaan menghasilkan niat konsumen untuk mengkonsumsinya lagi di masa yang akan dating (Wijaya, 2015). Disisi lain, keunggulan produk juga seringkali digunakan konsumen sebagai indikator nilai dari suatu produk menurut Diponugroho \& Santoso (2015), ada sebagian konsumen yang menjadikan keunggulan produk sebagai satu-satunya pertimbangan dalam melakukan pembelian ulang produk tersebut. Dengan begitu perusahaan harus memperlihatkan keunggulan produk sehingga, dapat menarik konsumen untuk melakukan pembelian kembali.

Keunggulan suatu produk dapat membantu konsumen dalam menentukan pilihannya terhadap suatu produk, semakin berkembangnya teknologi dalam dunia fashion saat ini menuntut perusahaan untuk selalu dapat meningkatkan keunggulan dari produk yang dihasilkan perusahaan tersebut Tripratiwi et al. (2016). Menurut Woran Nita, Tumbel Altje, (2016) mengatakan bahwa, produk menjadi suatu instrument vital untuk dapat mencapai kesuksesan serta kemakmuran dalam suatu perusahaan, selain itu produk akan sukses hanya apabila perusahaan mampu menghasilkan produk yang unggul begitu pula sebaliknya perusahaan akan gagal dalam mencapai tujuan bisnisnya karena produk yang dihasilkan tidak memiliki keunggulan sehingga tidak dapat bersaing dalam pasar. Posisi keunggulan produk dipandang dari sisi fungsional maupun harga yang dalam usahanya diharapkan menjadi pemenuh harapan seorang pelanggan dengan didukung oleh atribut-atribut fisik yang melekat pada produk tersebut. Studi empiris dilakukan Navarone (2003) menyatakan bahwa, keunggulan produk merupakan suatu hal yang mutlak sehingga harus dipertahankan oleh perusahaan. Atribut produk yang melengkapi suatu merek yang sesuai dengan manfaatnya, keunikan dan juga kelebihan yang berbeda dari perusahaan lain serta memiliki tingkat efisiensi produk merupakan kunci dari peningkatan kesuksesan sebuah produk serta, tentu dapat juga mengangkat niat beli ulang dari sebuah produk tersebut. Keunggulan produk juga dapat memengaruhi 
niat beli ulang konsumen, hal ini didukung oleh penelitian yang dilakukan oleh Tripratiwi et al. (2016) yang menyatakan bahwa, keunggulan produk akan tercapai melalui kualitas produk yang dimiliki oleh produk tersebut sehingga, keunggulan produk akan terbentuk dan mempunyai pengaruh yang positif serta signifikan dalam memengaruhi konsumen untuk melakukan pembelian ulang. Penelitian serupa juga dilakukan oleh Hadi (2013), kualitas produk dibangun terlebih dulu untuk mencapai keunggulan produk dan digunakan sebagai alat dalam meningkatkan keunggulan suatu produk serta dapat memengaruhi niat konsumen untuk membeli kembali. Penelitian mengenai keunggulan produk yang dilakukan oleh Tumbel \& Riaz (2015) menyatakan bahwa, keunggulan produk berpengaruh positif dan signifikan terhadap niat beli ulang konsumen. Hasil penelitian yang relevan juga diungkapkan oleh Kristiana dan Wahyudin (2012) yang menunjukkan bahwa, keunggulan produk berpengaruh positif dan signifikan terhadap niat beli ulang konsumen. Hasil yang bertentangan dikemukakan oleh Kurniawan et al. (2007) menyatakan bahwa, keunggulan produk tidak berpengaruh signifikan tehadap niat beli ulang dan oleh karena adanya research gap maka, pada penelitian ini diperlukan variabel mediasi dimana variabel mediasi dalam penelitian ini adalah citra merek. Niat beli ulang pada konsumen juga dapat ditingkatkan melalui citra merek yang kuat. Perusahaan bergantung pada merek sebagai strategi berkompetisi dengan pesaing karena merek dapat memberikan makna dan alasan terhadap hubungan perusahaan dengan konsumen (Hasan, 2013). Tingkat kesadaran merek yang tinggi dan citra yang positif diyakini akan meningkatkan kemungkinan produk untuk dipilih konsumen. Belakangan perkembangan bisnis di Indonesia menunjukkan keberhasilannya yang pesat dalam meraih laba serta menanamkan citra merek dalam benak konsumen. Semakin besarnya keberhasilan produk yang unggul tertanam dalam benak konsumen, menjadikan konsumen tersebut loyal atas suatu produk atau jasa yang disediakan oleh perusahaan atau pemasar (Nany, 2006).

Hal ini berdampak positif terhadap laba yang didapatkan perusahaan yang memiliki citra merek terhadap produk tersebut. Konsumen yang merasakan kepuasan akan suatu produk pilihannya memberikan pengaruh dalam benak konsumen untuk terus melakukan pembelian terhadap suatu produk atau jasa tersebut. Produk yang memiliki keunggulan akan menjadikan produk tersebut lebih menarik dan unik, juga akan menjadi ciri khas dari produk tersebut yang dapat membedakannya dengan produk pesaing (Fitriana \& Yulianti, 2016). Sebuah produk tentu memiliki citranya masing-masing didalam benak konsumen, ini disebabkan karena keunggulan produk merupakan sebuah identitas yang dapat membedakan suatu produk atau jasa dari perusahaan. Pada akhirnya, keunggulan produk menjadi hal penting dalam memengaruhi konsumen membeli kembali produk yang sudah diakuinya (Bian dan Moutinho, 2011). Suatu kreativitas dalam pengembangan suatu produk dapat dilakukan berdasarkan dari adanya permintaan pasar atau juga bisa disesuaikan dengan adanya perkembangan tekonologi. Hal ini berguna agar konsumen tidak merasa jenuh terhadap produk sehingga, memiliki minat untuk mencari alternatif lain yang sesuai dengan harapan dan keinginan mereka (Komaryatin dan Ella, 2006). Perusahaan mempunyai konsep untuk selalu menanamkan produknya di benak konsumen (Arslan \& Zaman, 2014). Perusahaan yang mempunyai citra yang baik akan mempunyai dampak yang menguntungkan 
sedangkan, citra yang buruk akan merugikan organisasi (Surya Ningrum, 2014). Keunggulan produk kuat yang dimiliki oleh perusahaan dapat meningkatkan kepercayaan konsumen dalam menggunakan kembali produk atau jasa yang dibeli (Jalilvand, 2012). Citra merek juga sering dijadikan sebagai isyarat ekstrinsik ketika konsumen mengevaluasi produk sebelum memutuskan untuk membeli (Wang \& Tsai, 2014). Hal ini sesuai dengan penelitian yang dilakukan oleh (Hadi, 2013) yang menyatakan bahwa, keunggulan produk menunjukkan efek yang positif dan signifikan dimana, keunggulan produk dapat memengaruhi citra merek suatu produk sehingga, semakin unggul suatu produk maka citra dari sebuah merek juga akan semakin tinggi.

Hasil penelitian sebelumnya yang sejalan dengan penelitian ini dikemukakan keunggulan produk berpengaruh positif terhadap citra merek dapat diterima dan dibuktikan secara statistik dalam penelitian (Hadi, 2013). Keunggulan adalah ciri dan sifat suatu produk yang berpengaruh untuk memuaskan kebutuhan konsumen baik yang dinyatakan maupun yang tersirat Kotler (2012:49). Keunggulan produk menjadi hal yang sangat penting karena itu menyangkut kepercayaan konsumen terhadap produk dan perusahaan itu sendiri sebagai produsen. Keunggulan produk berkaitan erat dengan citra merek, karena keunggulan produk yang baik akan melahirkan citra yang positif dibenak konsumen sehingga, konsumen menjadi percaya terhadap produk tersebut Anis dkk. (2015). Apabila keunggulan produk baik di mata konsumen maka, secara otomatis terbentuk citra merek yang positif di mata konsumen.

Keunggulan produk yang dimiliki perusahaan berkaitan erat dengan strategi pemasaran yang dilakukan. Strategi pemasaran yang efektif selalu diawali dengan informasi yang akurat mengenai siapa saja konsumen perusahaan. Dalam rangka menarik minat beli konsumen, apabila pemasar dapat menciptakan merek yang bisa menjadi pengikat antara pelanggan dan perusahaan maka, strategi pemasaran berjalan dengan efektif. Kepercayaan konsumen pada citra merek dapat diperoleh apabila pemasar dapat menciptakan serta mempertahankan hubungan emosional yang positif dengan konsumen, yang dibangun secara konsisten dalam jangka waktu yang cukup lama. Hal ini juga dikemukakan Purba (2011) bahwa, perusahaan harus memiliki strategi bersaing yang berbeda dengan yang dilakukan oleh perusahaan saingan sehingga, mampu menciptakan kepercayaan konsumen terhadap produk melalui hubungan emosional yang positif. Berdasarkan hasil penelitian mengemukakan bahwa, keunggulan produk berpengaruh positif dan signifikan terhadap citra merek Yusmawan et al. (2014). Berdasarkan hasil penelitian terdahulu juga mengemukakan bahwa, keunggulan produk berpengaruh positif dan signifikan terhadap citra merek (Erlangga \& Sisilia, n.d.). Berdasarkan uraian di atas maka, dapat diambil sebuah hipotesis sebagai berikut.

$\mathrm{H}_{1}$ : Keunggulan Produk berpengaruh positif dan signifikan terhadap Citra Merek

Hasil penelitian sebelumnya yang sejalan dengan penelitian ini dikemukakan oleh Sylvia (2003) dan Istijanto (2007) menyatakan bahwa, keunggulan produk berpengaruh positif dan signifikan terhadap niat beli ulang. Hal serupa juga ditemukan oleh (Hadi, 2013) dan (Tripratiwi et al. 2016) juga menyatakan bahwa, keunggulan produk berpengaruh positif terhadap niat beli 
ulang. Peneltian yang dilakukan oleh (Nusarika \& Purnami, 2015) menunjukan bahwa adanya hubungan positif antara keunggulan produk dengan niat pembelian kembali konsumen.

Pada dasarnya perilaku yang lampau dapat mempengaruhi minat (intention) secara langsung dan perilaku yang akan datang (future behavior). Menurut Zeithaml, dkk dalam Sivadas \& Baker Prewitt (2000) sebenarnya hubungan antara konsumen dengan perusahaan akan semakin kuat manakala konsumen memiliki penilaian baik terhadap keunggulan produk yang diberikan perusahaan dan sebaliknya, semakin lemah manakala konsumen atau pelanggan memiliki penilaian negatif terhadap keunggulan produk yang diberikan perusahaan. Perusahaan sangat penting menentukan produk yang tepat tentang apa yang konsumen butuhkan karena akan berpengaruh positif terhadap niat beli ulang konsumen (Tariq et al., 2013). Hasil penelitian yang relatif terbaru dari (Cronin \& Taylor, 1992) juga menunjukkan bahwa, keunggulan produk secara langsung maupun tidak langsung secara simultan mempengaruhi niat beli ulang. Hasil yang sama juga ditunjukkan dalam penelitian yang dilakukan oleh Waldi \& Santosa (2011) mereka menunjukkan bahwa, keunggulan produk memiliki pengaruh terhadap niat beli ulang konsumen. Berdasarkan uraian di atas maka, dapat diambil sebuah hipotesis sebagai berikut.

$\mathrm{H}_{2}$ : Keunggulan Produk berpengaruh positif dan signifikan terhadap Niat Beli Ulang.

Brand image adalah suatu persepsi konsumen tentang suatu merek, persepsi inilah yang nantinya akan mempengaruhi konsumen agar melakukan pembelian ulang suatu merek tertentu. Bila konsumen merasa puas, maka akan ada pembelian ulang terhadap produk tersebut. Suatu produk yang memiliki merek atau nama yang telah dikenal luas oleh masyarakat, biasanya memiliki daya tarik khusus yang akan menjadi bahan pertimbangan bagi konsumen untuk melakukan pembelian ulang produk. Pembelian ulang dipengaruhi oleh faktor brand image yang positif, karena dengan brand image yang kuat dapat menyebabkan konsumen menjadi loyal Andreani et al. (2012). Dengan demikian brand image merupakan salah satu faktor seseorang untuk melakukan pembelian ulang, karena dengan brand mage yang positif tersebut dapat membuat konsumen melakukan pembelian secara berulangulang.

Hasil penelitian yang sejalan dikemukan Pujadi (2010) dan Arista (2011) menyatakan bahwa, terdapat hubungan postif dan signifikan antara citra merek dan niat beli ulang. Hal serupa juga ditemukan oleh Subiyanto (2013) dan (Tripratiwi et al. 2016) yang menyatakan bahwa, citra merek memiliki hubungan positif terhadap niat beli ulang. Hasil penelitian yang dilakukan oleh Rimiyati \& Widodo, (2014) juga memberikan hasil bahwa, citra merek memberikan pengaruh secara parsial positif dan signifikan terhadap niat beli ulang konsumen. Berdasarkan uraian di atas maka dapat diambil sebuah hipotesis sebagai berikut.

$\mathrm{H}_{3}$ : Citra Merek berpengaruh positif dan signifikan terhadap Niat Beli Ulang.

Keputusan pembelian adalah pada tahap evaluasi, konsumen menyusun merek-merek dalam himpunan pilihan serta membentuk nilai pembelian. Biasanya konsumen akan memilih merek yang disukai tetapi, ada pula faktor yang mempengaruhi seperti keunggulan produk agar mampu menumbuhkan niat beli 
ulang konsumen. Menurut Ferinda Dewi (2009:203) berpendapat bahwa, citra merek adalah merupakan konsep yang diciptakan oleh konsumen karena alasan subjektif dan emosi pribadinya. Ditambahkan citra merek adalah persepsi tentang merek yang digambarkan oleh asosiasi merek yang ada dalam ingatan konsumen. Citra merek yang baik terhadap suatu produk akan meningkatkan persepsi yang baik pula terhadap konsumen. Dengan demikian, citra merek yang baik diimbangi dengan keunggulan produk akan menumbuhkan niat beli ulang bagi konsumen.

Keunggulan produk menjadi suatu hal penting yang dipertimbangkan konsumen sebelum konsumen memutuskan membeli suatu produk. Konsumen cenderung akan akan melakukan pembelian ulang apabila keunggulan produk yang dihasilkan baik sedangkan, konsumen akan beralih ke produk lain yang sejenis apabila keunggulan produk tidak sesuai dengan yang diharapkan konsumen. Apabila suatu produk diyakini oleh konsumen memiliki keunggulan produk yang baik dan dapat memenuhi kebutuhan dan keinginannya serta memiliki citra merek yang positif maka, secara tidak langsung mampu mendorong keputusan pembelian konsumen akan produk yang ditawarkan. Begitu juga sebaliknya, apabila citra merek produk yang ditawarkan negatif dimata konsumen dan produk memiliki keunggulan yang rendah maka, keputusan pembelian konsumen terhadap produk yang ditawarkan berkurang bahkan, konsumen bisa juga tidak memutuskan membeli produk tersebut. Konsumen senantiasa menilai kinerja produk yang dapat dilihat dari kemampuan produk dalam menciptakan keunggulan produk sehingga, mampu menarik niat konsumen untuk melakukan pembelian produk dan dengan keunggulan produk yang memuaskan konsumen itulah terbentuk citra merek yang positif dibenak konsumen. Keunggulan yang dimiliki suatu produk akan mempengaruhi persepsi dan keyakinan konsumen untuk membeli. Dengan keunggulan yang baik maka, citra merek yang sudah dibangun dan positif akan menambah niat beli ulang dimata konsumen. Berdasarkan hasil penelitian mengemukakan bahwa, keunggulan produk berpengaruh positif dan signifikan terhadap niat beli ulang melalui citra merek (Wahid, 2016). Peneliti terdahulu juga mengatakan bahwa, keunggulan produk memiliki pengaruh positif dan signifikan terhadap niat beli ulang Amrullah et al. (2016). Peneliti terdahulu mengatakan, keunggulan produk memiliki pengaruh positif dan signifikan terhadap citra merek (Gun, 2014). Peneliti terdahulu mengatakan, citra merek berpengaruh positif dan signifikan terhadap niat beli ulang (Listyawati, 2014).

Hasil penelitian sebelumnya yang sejalan dengan penelitian ini dikemukakan oleh Alim (2010) dan Norman (2014) menyatakan bahwa, adanya pengaruh positif keunggulan produk terhadap niat beli ulang dengan citra merek sebagai variabel mediasi. Hal ini berarti citra merek mampu memediasi secara signifikan pengaruh keunggulan produk terhadap niat beli ulang konsumen. Semakin baik citra merek yang didasarkan pada keunggulan produk maka, peningkatan niat beli ulang akan semakin baik begitu pula sebaliknya. Berdasarkan uraian di atas maka dapat diambil sebuah hipotesis sebagai berikut.

$\mathrm{H}_{4}$ : Citra Merek mampu memediasi secara signifikan pengaruh Keunggulan Produk dan Niat Beli Ulang 


\section{METODE PENELITIAN}

Penelitian ini dilakukan pada konsumen yang sudah pernah membeli produk fashion merek Uniqlo di Mal Bali Galeria. Adapun alasan pemilihan lokasi penelitian ini karena banyak sekali konsumen yang membeli produk fashion Uniqlo yang dikarenakan memiliki keunggulan produk serta diperkuat dengan citra merek yang dimiliki Uniqlo. Adapun objek dalam penelitian ini adalah citra merek, keunggulan produk, dan niat beli ulang produk fashion Uniqlo.

Populasi dalam penelitian ini adalah konsumen yang sudah pernah membeli produk fashion Uniqlo. Ukuran sampel dalam penelitian ini ditentukan dengan menggunakan analisis multivariate. Jika dalam penelitian menggunakan multivariate dalam melakukan analisis maka, jumlah anggota sampel minimal 10 kali dari jumlah variabel yang akan diteliti. Jumlah indikator yang digunakan dalan penelitian ini adalah 11 indikator $\mathrm{x} 10=110$ responden.

Teknik analisis dalam penelitian ini menggunakan Teknik analisis jalur. Analisis jalur merupakan perluasan dari analisis regresi linear berganda. Penggunaan analisis regresi untuk menaksir hubungan kausalitas antar variabel (model causal) yang telah ditetapkan sebelumnya berdasarkan teori. Model analisis jalur digunakan untuk menganalisis pola hubungan antar variabel dengan tujuan untuk mengetahui pengaruh langsung maupun tidak langsung seperangkat variabel independen (eksogen) terhadap variabel dependen (endogen).

\section{HASIL DAN PEMBAHASAN}

Suatu instrumen dikatakan valid jika korelasi antara skor faktor dengan skor total bernilai positif dan nilainya lebih dari 0,30 ( $\mathrm{r}>0,3)$. Berikut Tabel hasil pengujian validitas.

Tabel 1.

Hasil Uji Validitas

\begin{tabular}{ccccc}
\hline No & Variabel & Item Pernyataan & $\begin{array}{c}\text { Korelasi Item } \\
\text { Total }\end{array}$ & Keterangan \\
\hline \multirow{2}{*}{1} & Keunggulan & Keunggulan Desain & 0,759 & Valid \\
& Produk (X) & Keunggulan Bahan & 0,870 & Valid \\
& & Keunggulan Daya Tahan & 0,799 & Valid \\
& \multirow{4}{*}{2} & Minat Transaksional & 0,787 & Valid \\
& Niat Beli & Minat Referensial & 0,848 & Valid \\
& Ulang (Y) & Minat Preferensial & 0,884 & Valid \\
& & Minat Eksploratif & 0,894 & Valid \\
\multirow{2}{*}{3} & Citra Merek & Memiliki Image Positif & 0,868 & Valid \\
& (M) & Memiliki Ciri Khas & 0,808 & Valid \\
& & Merek Dikenal Luas & 0,827 & Valid \\
\hline
\end{tabular}

Sumber: Data diolah, 2020

Hasil uji validitas pada Tabel 1. menunjukkan bahwa seluruh variabel memiliki nilai koefisien korelasi dengan skor total seluruh item pernyataan lebih besar dari 0,30 . Hal ini menunjukkan bahwa, butir-butir pernyataan dalam instrumen penelitian tersebut valid. 
Suatu instrumen dikatakan reliabel, jika instrumen tersebut memiliki nilai Alpha Cronbach lebih dari 0,60. Adapun hasil dari uji reliabilitas dapat ditunjukkan pada Tabel berikut:

Tabel 2.

Hasil Uji Reliabilitas

\begin{tabular}{cccc}
\hline No & Variabel & Cronbach's Alpha & Keterangan \\
\hline 1 & Keunggulan Produk (X) & 0,830 & Reliabel \\
2 & Niat Beli Ulang (Y) & 0,830 & Reliabel \\
3 & Citra Merek (M) & 0,825 & Reliabel \\
\hline
\end{tabular}

Sumber: Data diolah, 2020

Suatu instrumen dikatakan reliabel jika, instrumen tersebut memiliki nilai Alpha Cronbach lebih dari 0,60. Hasil uji reliabilitas yang disajikan dalam Tabel 4.5 menunjukkan bahwa, setiap variabel memiliki nilai koefisien Alpha Cronbach lebih dari 0,6 . Hal ini dapat dikatakan bahwa, semua variabel dalam penelitian ini adalah reliabel.

Analisis statistik deskriptif berfungsi untuk menganalisis data dengan cara mendeskripsikan atau menggambarkan data yang telah terkumpul sebagaimana adanya tanpa bermaksud membuat kesimpulan yang berlaku untuk umum atau generalisasi. Hasil dari analisis statistik deskriptif yang diolah dengan bantuan software SPSS for Windows disajikan sebagai berikut:

Tabel 3.

Hasil Analisis Statistik Deskriptif

\begin{tabular}{cccccc}
\hline & N & Minimum & Maximum & Mean & Std. Deviation \\
\hline Keunggulan Produk & 110 & 9 & 15 & 12.86 & 1.732 \\
Citra Merek & 110 & 10 & 20 & 16.90 & 2.389 \\
Niat Beli Ulang & 110 & 6 & 20 & 15.17 & 3.047 \\
Valid N (listwise) & 110 & & & & \\
\hline
\end{tabular}

Sumber: Data diolah, 2020

Statistik deskriptif pada Tabel 3. menunjukkan bahwa, nilai minimum dan maksimum variabel keunggulan produk sebesar 9 dan 15. Rata-ratanya (mean) sebesar 12,86 dengan standar deviasi sebesar 1,732 hal ini berarti bahwa, terjadi perbedaan nilai keunggulan produk yang diteliti terhadap nilai rata-ratanya sebesar 1,732. Nilai minimum dan maksimum variabel citra merek sebesar 10 dan 20 . Rataratanya (mean) sebesar 16,90 dengan standar deviasi sebesar 2,389 hal ini berarti bahwa, terjadi perbedaan nilai citra merek yang diteliti terhadap nilai rata-ratanya sebesar 2,389. Nilai minimum dan maksimum variabel niat beli ulang sebesar 6 dan 20. Rata-ratanya (mean) sebesar 15,17 dengan standar deviasi sebesar 3,047 hal ini berarti bahwa, terjadi perbedaan nilai niat beli ulang yang diteliti terhadap nilai rataratannya sebesar 3,047.

Untuk menguji apakah data yang digunakan normal atau tidak dapat dilakukan dengan menggunakan uji Kolmogorov Smirnov. Apabila koefisien Asymp. Sig. (2-tailed) lebih besar dari 0,05 maka, data tersebut akan berdistribusi normal. 
Tabel 4.

Hasil Uji Normalitas Struktur 1

\begin{tabular}{cc}
\hline & Unstandardized Residual \\
\hline $\mathrm{N}$ & 110 \\
Kolmogorov-Smirnov & 0,579 \\
Asymp. Sig. (2-tailed) & 0,892 \\
\hline
\end{tabular}

Sumber: Data diolah, 2020

Berdasarkan Tabel 4. dapat dilihat bahwa, nilai Kolmogorov Smirnov (K-S) sebesar 0,579 sedangkan, Asymp. Sig. (2-tailed) sebesar 0,892. Hasil tersebut mengindikasikan bahwa, model persamaan regresi tersebut berdistribusi normal karena nilai Asymp. Sig. (2-tailed) lebih besar dari nilai alpha 0,05.

Tabel 5.

Hasil Uji Normalitas Struktur 2

\begin{tabular}{cc}
\hline & Unstandardized Residual \\
\hline $\mathrm{N}$ & 110 \\
Kolmogorov-Smirnov & 0,073 \\
Asymp. Sig. (2-tailed) & 0,200 \\
\hline
\end{tabular}

Sumber: Data diolah, 2020

Berdasarkan Tabel 5. dapat dilihat bahwa, nilai Kolmogorov Smirnov (K-S) sebesar 0,073 sedangkan, Asymp. Sig. (2-tailed) sebesar 0,200. Hasil tersebut mengindikasikan bahwa, model persamaan regresi tersebut berdistribusi normal karena nilai Asymp. Sig. (2-tailed) lebih besar dari nilai alpha 0,05.

Uji yang menilai apakah ada ketidaksamaan varian dari residual untuk semua pengamatan pada model regresi linear. Apabila asumsi heteroskedastistas tidak terpenuhi maka, model regresi dinyatakan tidak valid sebagai alat peramalan dan pengujian ini dilakukan dengan uji Glejser. Jika signifikansinya diatas 0,05 maka, tidak mengandung heteroskedastisitas.

Tabel 6.

Hasil Uji Heteroskedastisitas Struktur 1

\begin{tabular}{|c|c|c|c|c|c|}
\hline \multirow[t]{2}{*}{ Model } & \multicolumn{2}{|c|}{$\begin{array}{c}\text { Unstandardized } \\
\text { Coefficients }\end{array}$} & \multirow{2}{*}{$\begin{array}{c}\begin{array}{c}\text { Standardized } \\
\text { Coefficients }\end{array} \\
\text { Beta }\end{array}$} & \multirow[t]{2}{*}{$\mathbf{t}$} & \multirow[t]{2}{*}{ Sig. } \\
\hline & B & Std. Error & & & \\
\hline$($ Constant $)$ & 1,431 & 0,728 & & 1,965 & 0,052 \\
\hline $\begin{array}{l}\text { Keunggulan } \\
\text { Produk }\end{array}$ & $-0,017$ & 0,056 & $-0,029$ & $-0,300$ & 0,764 \\
\hline
\end{tabular}

Sumber: Data diolah, 2020

Berdasarkan Tabel 6. dapat dilihat bahwa, nilai signifikansi dari variabel keunggulan produk sebesar 0,764 . Nilai tersebut lebih besar dari 0,05 yang berarti tidak terdapat pengaruh antara variabel bebas terhadap absolute residual. Sehingga, model yang dibuat tidak mengandung heteroskedastisitas. 
Tabel 7.

Hasil Uji Heteroskedastisitas Struktur 2

\begin{tabular}{|c|c|c|c|c|c|}
\hline \multirow[t]{2}{*}{ Model } & \multicolumn{2}{|c|}{$\begin{array}{c}\text { Unstandardized } \\
\text { Coefficients }\end{array}$} & \multirow{2}{*}{$\begin{array}{c}\text { Standardized } \\
\text { Coefficients } \\
\text { Beta } \\
\end{array}$} & \multirow[t]{2}{*}{$\mathbf{t}$} & \multirow[t]{2}{*}{ Sig. } \\
\hline & B & Std. Error & & & \\
\hline$($ Constant $)$ & 2,374 & 1,031 & & 2,302 & 0,023 \\
\hline $\begin{array}{l}\text { Keunggulan } \\
\text { Produk }\end{array}$ & $-0,207$ & 0,115 & $-0,259$ & $-1,803$ & 0,074 \\
\hline Citra Merek & 0,118 & 0,083 & 0,203 & 1,417 & 0,159 \\
\hline
\end{tabular}

Sumber: Data diolah, 2020

Berdasarkan Tabel 7. dapat dilihat bahwa, nilai signifikansi dari variabel keunggulan produk sebesar 0,074 dan variabel citra merek sebesar 0,159 . Nilai tersebut lebih besar dari 0,05 yang berarti tidak terdapat pengaruh antara variabel independen terhadap absolute residual. Sehingga, model yang dibuat tidak mengandung heteroskedastisitas.

Uji multikolinearitas bertujuan untuk menguji apakah pada model regresi ditemukan adanya korelasi antar variabel independen. Adanya multikolinearitas dapat dilihat dari nilai tolerance atau variance inflation factor (VIF). Jika nilai tolerance lebih dari 0,10 atau VIF kurang dari 10 maka, dikatakan tidak ada multikolinearitas.

\section{Tabel 8.}

Hasil Uji Multikolinearitas

\begin{tabular}{ccc}
\hline Variabel & Tolerance & VIF \\
\hline Keunggulan Produk & 0,440 & 2,274 \\
Citra Merek & 0,440 & 2,274 \\
\hline
\end{tabular}
Sumber: Data diolah, 2020

Berdasarkan Tabel 8. dapat dilihat bahwa, nilai tolerance dan VIF dari variabel keunggulan produk dan citra merek menunjukan nilai VIF lebih kecil dari 10 yang berarti model persamaan regresi bebas dari multikolinearitas.

Analisis untuk dapat menyusun persamaan struktural yang digunakan maka, terlebih dahulu data yang diperoleh diolah dan dihitung menggunakan program SPSS sehingga, diperoleh hasil analisis seperti pada Tabel 9 dan 10.

Tabel 9.

Hasil Analisis Jalur Persamaan Regresi 1

\begin{tabular}{cccccc}
\hline Model & \multicolumn{2}{c}{ Unstandardized Coefficients } & $\begin{array}{c}\text { Standardized } \\
\text { Coefficients } \\
\text { Beta }\end{array}$ & t & Sig. \\
\hline $\begin{array}{c}\text { (Constant) } \\
\text { Keunggulan }\end{array}$ & 3,621 & 1,142 & & 3,170 & 0,002 \\
$\begin{array}{l}\text { Produk } \\
\mathrm{R}^{2}: 0,560\end{array}$ & 1,032 & 0,088 & 0,748 & 11,729 & 0,000 \\
\hline
\end{tabular}

Sumber: Data diolah, 2020

Berdasarkan hasil analisis jalur substruktur 1 seperti yang disajikan pada Tabel 9. maka, persamaan strukturnya adalah sebagai berikut :

$$
\mathrm{M}=0,748 \mathrm{X}
$$


Tabel 10.

Hasil Analisis Jalur Persamaan Regresi 2

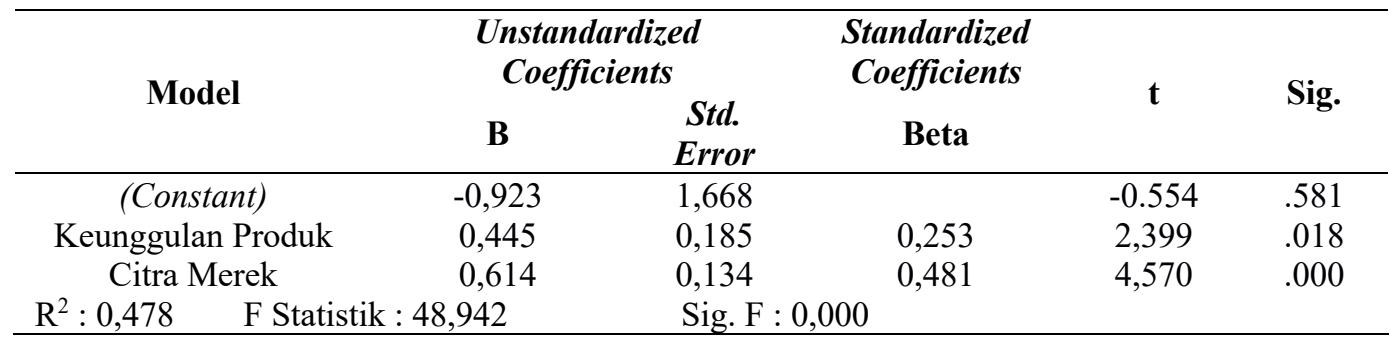

Sumber: Data diolah, 2020

Berdasarkan hasil analisis jalur substruktur 2 seperti yang disajikan pada Tabel 10. maka, persamaan strukturalnya adalah sebagai berikut :

$$
\mathrm{Y}=0,253 \mathrm{X}+0,481 \mathrm{M}+\varepsilon_{2}
$$

Pengaruh variabel keunggulan produk $(\mathrm{X})$ terhadap niat beli ulang $(\mathrm{Y})$ dengan citra merek (M) sebagai variabel mediasi :

$$
\begin{aligned}
\text { indirect effect } & =\beta_{1} \times \beta_{3} \ldots \ldots \ldots \ldots \ldots \ldots .(1) \\
& =0,748 \times 0,481 \\
& =0,359
\end{aligned}
$$

Total pengaruh variabel keunggulan produk $(\mathrm{X})$ terhadap niat beli ulang $(\mathrm{Y})$ melalui citra merek $(\mathrm{M})$ sebagai berikut :

$$
\begin{aligned}
\text { total effect } & =\beta_{2}+\left(\beta_{1}\right) \times\left(\beta_{3}\right) \ldots \ldots \ldots \ldots \\
& =0,253+(0,748 \times 0,481) \\
& =0,612
\end{aligned}
$$

Berdasarkan model substruktur 1 dan substruktur 2 maka, dapat disusun model diagram jalur akhir. Sebelum menyusun model diagram jalur akhir, terlebih dahulu dihitung nilai standar error sebagai berikut :

$$
\begin{aligned}
& \mathrm{Pe}_{\mathrm{i}}=\sqrt{1-\mathrm{R}_{\mathrm{i}}{ }^{2}} \text {. } \\
& \mathrm{Pe}_{1}=\sqrt{1-R_{1}^{2}}=\sqrt{1-0,560^{2}}=0,828 \\
& \mathrm{Pe}_{2}=\sqrt{1-R_{2}{ }^{2}}=\sqrt{1-0,478^{2}}=0,878
\end{aligned}
$$

Berdasarkan perhitungan pengaruh error (Pei), didapatkan hasil pengaruh error $\left(\mathrm{Pe}_{1}\right)$ sebesar 0,828 dan pengaruh error $\left(\mathrm{Pe}_{2}\right)$ sebesar 0,878. Hasil koefisien determinasi total adalah sebagai berikut :

$$
\begin{aligned}
\mathrm{R}^{2}{ }_{\mathrm{m}} & =1-\left(\mathrm{Pe}_{1}\right)^{2}\left(\mathrm{Pe}_{2}\right)^{2} \\
& =1-(0,828)^{2}(0,878)^{2} \\
& =0,471
\end{aligned}
$$

Nilai determinasi total sebesar 0,471 mempunyai arti bahwa, sebesar 47,1 persen variasi keunggulan produk dipengaruhi oleh variasi citra merek dan niat beli ulang sedangkan, sisanya sebesar 52,9 persen dijelaskan oleh faktor lain yang tidak dimasukkan ke dalam model.

Berdasarkan hasil pengujian pada Tabel 9 .dan 10. menghasilkan koefisien F $\leq 0,05$ dengan koefisien signifikan $\leq 0,05$ hal tersebut menunjukkan keunggulan produk dan citra merek berpengaruh secara simultan dan signifikan terhadap niat beli ulang. Berdasarkan hasil analisis pengaruh keunggulan produk terhadap citra merek diperoleh nilai Sig. $t$ sebesar 0,000 dengan nilai koefisien beta 0,478 . Nilai 
Sig. t $0,000<0,05$ mengindikasikan bahwa, $\mathrm{H}_{0}$ ditolak dan $\mathrm{H}_{1}$ diterima. Hasil ini mempunyai arti bahwa, keunggulan produk berpengaruh positif dan signifikan terhadap citra merek.

Berdasarkan hasil analisis pengaruh keunggulan produk terhadap niat beli ulang diperoleh nilai Sig. $t$ sebesar 0,018 dengan nilai koefisien beta 0,253. Nilai Sig. t $0,018<0,05$ mengindikasikan bahwa, $\mathrm{H}_{0}$ ditolak dan $\mathrm{H}_{2}$ diterima. Hasil ini mempunyai arti bahwa, keunggulan produk berpengaruh positif dan signifikan terhadap niat beli ulang.

Berdasarkan hasil analisis pengaruh citra merek terhadap niat beli ulang diperoleh nilai Sig. $t$ sebesar 0,000 dengan nilai koefisien beta 0,481 . Nilai Sig. t $0,000<0,05$ mengindikasikan bahwa, $\mathrm{H}_{0}$ ditolak dan $\mathrm{H}_{3}$ diterima. Hasil ini mempunyai arti bahwa, citra merek berpengaruh positif dan signifikan terhadap niat beli ulang.

Hasil koefisien jalur pada hipotesis penelitian dapat digambarkan pada Gambar 1. Berdasarkan diagram jalur pada Gambar 4.1 maka, dapat dihitung besarnya pengaruh langsung dan pengaruh tidak langsung serta pengaruh total antar variabel.

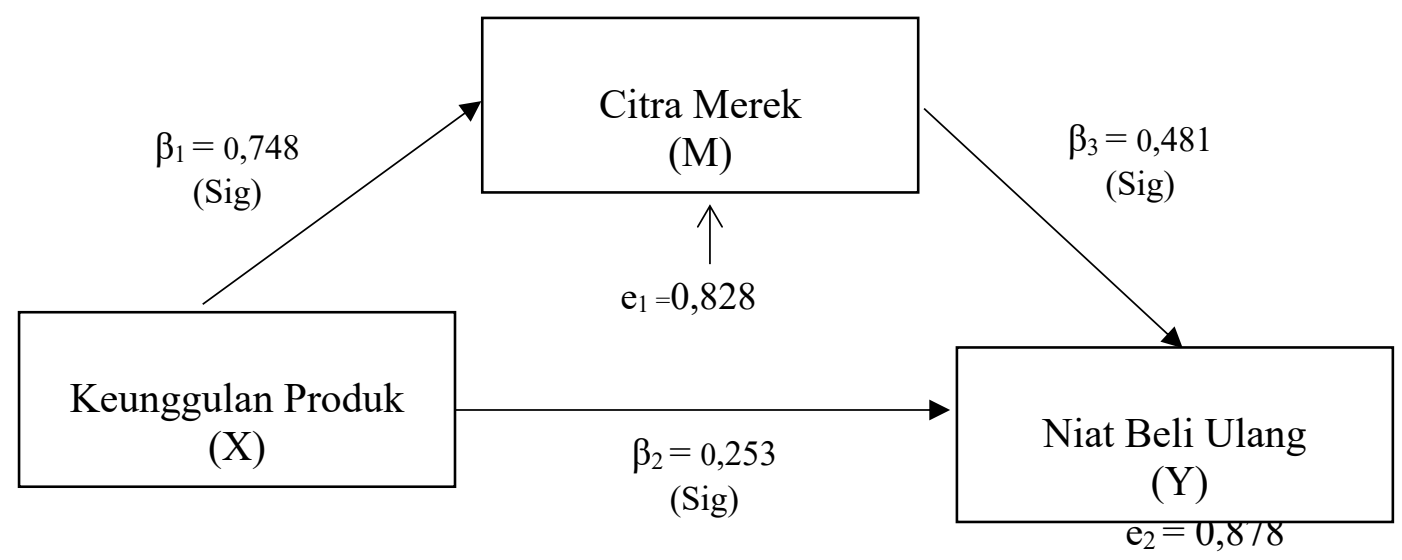

Gambar 1. Validasi Model Diagram Jalur Akhir

Sumber: Data diolah, 2020

Tabel 11.

Pengaruh Langsung, Pengaruh Tidak Langsung dan Pengaruh Total Keunggulan Produk (X), Citra Merek (M) dan Niat Beli Ulang (Y)

\begin{tabular}{cccc}
\hline Pengaruh Variabel & $\begin{array}{c}\text { Pengaruh } \\
\text { Langsung }\end{array}$ & $\begin{array}{c}\text { Pengaruh Tidak Langsung Melalui } \\
\text { Citra Merek } \\
(\mathbf{M})=(\boldsymbol{\beta 1} \mathbf{~ x 3})\end{array}$ & $\begin{array}{c}\text { Pengaruh } \\
\text { Total }\end{array}$ \\
\hline $\begin{array}{c}\text { Keunggulan Produk } \rightarrow \\
\quad \text { Citra Merek }\end{array}$ & 0,748 & - & 0,748 \\
$\begin{array}{c}\text { Keunggulan Produk } \\
\rightarrow \text { Niat Beli Ulang }\end{array}$ & 0,253 & 0,359 & 0,612 \\
$\begin{array}{c}\text { Citra Merek } \rightarrow \text { Niat } \\
\text { Beli Ulang }\end{array}$ & 0,481 & - & 0,481 \\
\hline
\end{tabular}

Sumber: Data diolah, 2020

Uji sobel merupakan alat analisis untuk menguji signifikansi dari hubungan tidak langsung antara variabel eksogen dengan variabel endogen yang dimediasi 
oleh variabel mediator. Uji sobel dirumuskan dengan persamaan berikut dan dapat dihitung dengan menggunakan aplikasi Microsoft Excel 2007.Penghitungan variabel mediasi menggunakan statistik uji

Uji sobel dihitung dengan rumus dibawah ini :

$$
\begin{aligned}
& S_{b 1 b 3}=\sqrt{b 3^{2} S_{b 1}^{2}+b 1^{2}} S_{b 3}^{2} \ldots \ldots \ldots \ldots \ldots \ldots \ldots \ldots \ldots . . .(5) \\
& S_{\mathrm{b} 1 \mathrm{~b} 3}=\sqrt{(0,614)^{2}(0,088)^{2}+(1,032)^{2}(0,134)^{2}} \\
& \mathrm{~S}_{\mathrm{b} 1 \mathrm{~b} 3}=0,023
\end{aligned}
$$

Untuk menguji signifikansi pengaruh tidak langsung maka, menghitung nilai $\mathrm{z}$ dari koefisien ab dengan rumus sebagai berikut :

$$
\begin{aligned}
& Z=\frac{b_{1} b_{3}}{S b_{1} b_{3}} \ldots \ldots \ldots . \\
& Z=\frac{(1,032)(0,614)}{0,023} \\
& Z=27,549
\end{aligned}
$$

Hasil dari pengujian variabel mediasi didapatkan $\mathrm{Z}$ hitung sebesar 27,549 > 1,96 yang berarti $\mathrm{H}_{0}$ ditolak dan $\mathrm{H}_{1}$ diterima, yang berarti variabel citra merek memediasi variabel keunggulan produk terhadap niat beli ulang produk fashion Uniqlo.

Kriteria penelitian pengujian efek mediasi yang berdasarkan hasil kalkulasi nilai $V A F$. Perhitungan $V A F$ dengan hasil lebih dari $80 \%$ dapat dikatakan variabel memiliki sifat memediasi secara penuh (full mediation), apabila perhitungan $V A F$ dengan hasil yang diantara lebih dari $20 \%$ hingga kurang dari $80 \%$ dapat dikatakan variabel memiliki sifat memediasi secara parsial (partial mediation) dan ketika perhitungan $V A F$ dengan hasil kurang dari $20 \%$ dapat dikatakan variabel bukan bersifat memediasi. Berikut hasil penghitungan $V A F$ :

$$
V A F=\frac{0,359}{0,612} \times 100 \%=58,66 \%
$$

Karena nilai $V A F$ sebesar 58,66\% yang dimana lebih dari $20 \%$ maka, dapat disimpulkan bahwa efek mediasi citra merek dikategorikan sebagai pemediasi parsial (partial mediation).

Berdasarkan hasil analisis keunggulan produk berpengaruh positif dan signifikan terhadap citra merek yang menunjukkan bahwa, keunggulan produk yang baik akan melahirkan citra yang positif dibenak konsumen sehingga, konsumen menjadi percaya terhadap produk dan apabila keunggulan produk baik di mata konsumen maka, secara otomatis terbentuk citra merek yang positif di mata konsumen.

Hasil rangkuman penilaian yang dilakukan responden terhadap keunggulan produk berada dalam kategori sangat tinggi sehingga, tingkat keunggulan produk terhadap produk fashion Uniqlo mendapat penilaian baik. Hasil penelitian ini sesuai dengan studi yang dilakukan oleh Agus (2017) bahwa variabel keunggulan produk memiliki pengaruh positif dan signifikan terhadap ekuitas merek. Pengaruh positf dikarenakan jika produk tersebut unggul maka, kekuatan ekuitas merek dari produk tersebut akan meningkat. Dari penelitian tersebut juga dikatakan bahwa, peran keunggulan produk dapat membuat konsumen melakukan keputusan pembelian kembali dan memperkuat ekuitas merek. Hal ini juga dikemukakan Purba (2011) 
bahwa, perusahaan harus memiliki strategi bersaing yang berbeda dengan yang dilakukan oleh perusahaan saingan sehingga, mampu menciptakan kepercayaan konsumen terhadap produk melalui hubungan emosional yang positif. Berdasarkan hasil penelitian mengemukakan bahwa, keunggulan produk berpengaruh positif dan signifikan terhadap citra merek Yusmawan et al. (2014). Dari pernyataan tersebut dapat disimpulkan bahwa, apabila ingin bersaing perusahaan haruslah memperhatikan produk tersebut dengan baik dan benar maka, kekuatan merek di benak konsumen akan semakin kuat.

Berdasarkan hasil analisis keunggulan produk berpengaruh positif dan signifikan terhadap niat beli ulang yang menunjukan bahwa, semakin unggul pada suatu produk maka tingkat kesetiaan atau loyalitas konsumen terhadap suatu produk akan semakin tinggi dan sebaliknya jika produk tidak unggul maka, potensi terjadinya niat beli ulang akan rendah.

Hasil rangkuman penilaian yang dilakukan responden terhadap niat beli ulang berada dalam kategori tinggi. Hal ini berarti secara keseluruhan responden mempresentasikan bahwa, sebagian besar responden loyal terhadap produk fashion Uniqlo karena mereka mengetahui keunggulan dari produk Uniqlo. Pada dasarnya perilaku yang lampau dapat mempengaruhi minat (intention) secara langsung dan perilaku yang akan datang (future behavior). Hasil penelitian sebelumnya yang sejalan dengan penelitian ini dikemukakan oleh Sylvia (2003) dan Istijanto (2007) menyatakan bahwa, keunggulan produk berpengaruh positif dan signifikan terhadap niat beli ulang. Hal serupa juga ditemukan oleh Hadi (2013) dan Tripratiwi et al. (2016) juga menyatakan bahwa, keunggulan produk berpengaruh positif terhadap niat beli ulang. Peneltian yang dilakukan oleh Nusarika \& Purnami (2015)menunjukan bahwa adanya hubungan positif antara keunggulan produk dengan niat pembelian kembali konsumen. Dari pernyataan tersebut dapat disimpulkan bahwa, apabila ingin bersaing perusahaan haruslah memperhatikan produk tersebut dengan baik dan benar maka, keinginan untuk membeli kembali di benak konsumen akan semakin tinggi.

Berdasarkan hasil analisis citra merek berpengaruh positif dan signifikan terhadap niat beli ulang yang menunjukkan bahwa, semakin tinggi tingkat ingatan konsumen mengenai merek atau brand maka semakin meningkat niat pembelian kembali pada konsumen dan sebaliknya jika citra merek Uniqlo menurun maka, potensi terjadinya niat beli ulang akan rendah.

Hasil rangkuman penilaian yang dilakukan responden terhadap citra merek berada dalam kategori sangat tinggi sehingga, tingkat citra merek terhadap produk fashion Uniqlo mendapat penilaian baik. Konsep citra dalam dunia bisnis telah berkembang dan menjadi perhatian para pemasar. Citra yang baik dari suatu organisasi akan mempunyai dampak yang menguntungkan sedangkan, citra yang jelek akan merugikan organisasi. Konsumen yang memiliki persepsi yang baik terhadap suatu merek, akan lebih memungkinkan untuk melakukan pembelian kembali terhadap produk tersebut. Selain itu citra merek yang dikenal dengan baik diharapkan akan mampu menarik perhatian yang besar sehingga, dapat menjadikan konsumen untuk membelinya dan memberikan kepuasan (Edi Purnomo, 2015). Selanjutnya menurut Darmawangsa \& Sri Ardani (2015) citra merek berpengaruh positif dan signifikan terhadap niat beli ulang konsumen. Ini menunjukkan bahwa, 
semakin kuat citra suatu merek semakin kuat pula niat beli ulang yang ditunjukkan konsumen pada merek tersebut. Hasil penelitian yang dilakukan oleh Rimiyati \& Widodo (2014)juga memberikan hasil bahwa, citra merek memberikan pengaruh secara parsial positif dan signifikan terhadap niat beli ulang konsumen. Dari pernyataan tersebut dapat disimpulkan bahwa, apabila kekuatan merek di benak konsumen semakin kuat maka, niat beli ulang konsumen terhadap merek tersebut akan semakin tinggi.

Pengaruh keunggulan produk terhadap niat beli ulang yang dimediasi oleh citra merek pada produk fashion Uniqlo telah diuji dalam penelitian ini yang menunjukkan bahwa, citra merek memediasi pengaruh keunggulan produk terhadap niat beli ulang secara parsial. Uji sobel yang telah dihitung memperkuat hasil tersebut dengan nilai koefisien $\mathrm{z}$ yang diperoleh adalah 27,549 $>1,96$ dengan tingkat signifikansi $0,000<0,05$ sehingga, dapat dikatakan bahwa citra merek memediasi pengaruh keunggulan produk terhadap niat beli ulang. Hal ini sesuai dengan penelitian yang dilakukan oleh $\mathrm{Hu}$ (2012) dengan hasil citra merek memediasi hubungan antara keunggulan produk dan niat beli ulang konsumen, ini berarti citra merek memainkan peran penting untuk mempengaruhi persepsi konsumen terhadap keunggulan suatu produk dan terhadap niat pembelian kembali. Dapat dikatakan bahwa, semakin unggulnya suatu produk yang dilakukan oleh Uniqlo maka, didalam pikiran konsumen akan semakin ingat pada merek Uniqlo hal tersebut nantinya mempengaruhi seseorang untuk tidak berpindah pada merek lain dan akan tetap setia serta melukakan pembelian kembali pada produk fashion Uniqlo.

Hasil penelitian ini memiliki implikasi teoritis dan praktis. Secara teoritis penelitian ini menunjukan bahwa, keunggulan produk dan citra merek berpengaruh positif dan signifikan terhadap niat beli ulang konsumen. Dengan demikian, hasil penelitian ini memberikan dukungan empiris dan dapat dinyatakan memperkuat hasil-hasil studi terdahulu. Secara praktis dari penelitian ini diharapkan bagi perusahaan Uniqlo dapat lebih memperhatikan niat beli ulang konsumen yang dipengaruhi oleh keunggulan produk dan juga citra merek yang ditunjukan oleh koefisien determinasi sebesar 47,1 persen namun, diperhatikan juga faktor lain yang dapat mempengaruhi niat beli ulang. Penelitian ini juga diharapkan dapat memberikan kontribusi yang positif bagi perusahaan Uniqlo untuk terus berinovasi dan mengembangkan strategi perusahaan.

Beberapa keterbatasan penelitian yang terdapat dalam penelitian ini adalah ruang lingkup penelitian ini hanya di Uniqlo Mal Bali Galeria sehingga, hasil penelitian tidak dapat digeneralisir untuk wilayah yang lebih luas. Penelitian ini hanya dilakukan dalam titik waktu tertentu (cross section) sedangkan, lingkungan setiap saat dapat berubah (dinamis) sehingga, penelitian ini penting untuk dilakukan kembali di masa mendatang.

\section{SIMPULAN}

Keunggulan produk berpengaruh positif dan signifikan terhadap citra merek produk fashion Uniqlo. Dapat dikatakan bahwa, keunggulan produk yang baik akan melahirkan citra yang positif dibenak konsumen sehingga, konsumen menjadi 
percaya terhadap produk dan apabila keunggulan produk baik di mata konsumen maka, secara otomatis terbentuk citra merek yang positif di mata konsumen.

Keunggulan produk berpengaruh positif dan signifikan terhadap niat beli ulang produk fashion Uniqlo. Dapat dikatakan bahwa, semakin unggul pada suatu produk maka tingkat kesetiaan atau loyalitas konsumen terhadap suatu produk akan semakin tinggi untuk melakukan pembelian kembali.

Citra merek berpengaruh positif dan signifikan terhadap niat beli ulang produk fashion Uniqlo. Dapat dikatakan bahwa, semakin tinggi tingkat ingatan konsumen mengenai merek atau brand maka semakin meningkat niat pembelian kembali pada konsumen. Citra merek memediasi pengaruh keunggulan produk terhadap niat beli ulang produk fashion Uniqlo. Ini berarti citra merek memainkan peran penting untuk mempengaruhi persepsi konsumen pada keunggulan produk dan niat beli ulang. Dapat dikatakan bahwa, semakin unggulnya suatu produk yang dilakukan oleh Uniqlo maka didalam pikiran konsumen akan semakin ingat pada merek Uniqlo hal tersebut nantinya mempengaruhi seseorang untuk tidak berpindah pada merek lain dan akan tetap setia serta melukakan pembelian kembali pada produk fashion Uniqlo.

Disarankan bagi peneliti selanjutnya diharapkan mampu memperluas cakupan penelitian ke wilayah lain dan menambahkan variabel-variabel lain yang dapat mempengaruhi niat beli ulang konsumen, seperti variabel persepsi harga, kepuasan konsumen, kepercayaan, sikap dan sebagainya agar memberikan hasil yang lebih baik lagi.

\section{REFERENSI}

Amrullah, Siburian, P. S., \& ZA, S. Z. (2016). Pengaruh Kualitas Produk dan Kualitas Layanan Terhadap Keputusan Pembelian Sepeda Motor Honda. Kinerja: Jurnal Ekonomi Dan Manajemen, 13(2), 99-118. http://journal.feb.unmul.ac.id/index.php/KINERJA/article/view/826

Anis L.M., Suharyono, Sunarti (2015). Pengaruh Kualitas Produk Terhadap International Brand Image Serta Dampaknya Terhadap Keputusan Pembelian Mahasiswa Pembeli Dan Pengguna Laptop Lenovo Di Fakultas Ilmu Administrasi Universitas Brawijaya. Jurnal Administrasi Bisnis, Vol. 28, No. 2, Malang: Universitas Brawijaya Malang.

Arista, E.D. \& Astuti, S.R.T (2011). Analisis Pengaruh Iklan, Kepercayaan Merek, dan Citra Merek terhadap Minat Beli Konsumen. Jurnal Ilmu Ekonomi ASET. 13(1), Pp: 37-45.

Arslan, M., \& Zaman, R. (2014). Impact of Brand Image and Service Quality on Consumer Purchase Intention: A Study of Retail Store in Pakistan. 4(22), 2225-2484.

Bian, Xuemei \& Luiz Moutinho (2011). The Role Of Brand Image, Product Involvement, And Knowledge In Explaining Consumer Purchase Behaviour Of Counterfits. European Journal of Marketing. 45(1/2): pp: 191-216. 
Cronin, J. J., \& Taylor, S. A. (1992). Measuring Service Quality: A Reexamination and Extension. Journal of Marketing, 56(3), 55. https://doi.org/10.2307/1252296

Darmawangsa, A., \& Sri Ardani, I. (2015). Pengaruh Komunikasi Pemasaran Terpadu Dan Ekuitas Merek Terhadap Loyalitas Konsumen. E-Jurnal Manajemen Universitas Udayana, 4(8), 255354.

Dewi, Ni Wayan Priti Nirmala \& Suparna, Gede (2017). Peran Inovasi Dalam Memediasi Pengaruh Orientasi Kewirausahaan Terhadap Keunggulan Bersaing Industri Kain Endek. E-Jurnal Manajemen Unud, Vol. 6, No. 9, 2017: 5144-5174.

Diponugroho, A., \& Santoso, S. B. (2015). Analisis Pengaruh Kualitas Produk dan Kemampuan Inovasi terhadap Minat Beli Ulang dengan Daya Tarik Produk Sebagai Variabel Intervening (Studi pada Parlour Café Semarang). Diponegoro Journal of Management, 4(3), 1-9.

Erlangga, D., \& Sisilia, K. (n.d.). Pengaruh Kualitas Pelayanan Terhadap Brand Image ( Studi pada Hotel Nusantara di Bandar Lampung ). Bandung.

Fatmawati, D., Triastity, R., \& Sunarso. (2017). Pengaruh Kualitas Produk dan Citra Merek Terhadap Keputusan Pembelian dengan Kepercayaan sebagai Variabel Intervening (Survei pada Konsumen Lumbung Batik Surakarta). Jurnal Ekonomi Dan Kewirausahaan, 17(2), 317-329.

Ferinda Dewi, Erna (2009). Merek dan Psikologi Konsumen, Implikasi pada Strategi Pemasaran, Yogyakarta: Graha Ilmu.

Fitriana, D., \& Yulianti, I. (2016). Pengaruh Brand Image Terhadap Purchase Intention.

Hadi, R. K. (2013). Pengaruh Keunggulan Produk Terhadap Minat Beli Konsumen Pada Produk Rangka Atap Baja Ringan Taso C75.75. Pengaruh Keunggulan Produk Terhadap Minat Beli Konsumen Pada Produk Rangka Atap Baja Ringan Taso C75.75, 12(3), 346-356. https://doi.org/10.14710/jspi.v12i3.346-356.

Hu, Y. J. (2012). The Moderating Effect of Brand Equity and The Mediating Effect of Marketing Mix Strategy on The Relationship Between Service Quality and Customer Loyalty: The Case of Retail Chain Stores in Taiwan. The International Journal of Organizational Innovation, 5(1), 155-162.

Ishak, Asmani (2011). Pengaruh Penggunaan Selebriti Dalam Iklan Terhadap Minat Beli Ulang Konsumen, Jurnal Siasat Bisnis Vol. 12 No. 2, Hal: 71-88, 2011.

Istijanto (2007). Delapan Dimensi Kualitas Produk dan Aplikasinya Dalam Pemasaran. Forum Manjaemen Prasetya Mulia, Vol. I, No.8. 
Jalilvand, M.R. (2012). The Effect of Electronic Word-of-Mouth on Brand Image and Purchase Intention. Journals of Marketing Inteligence and Planning. 30(4), 5-5.

Komaryatin, Nurul \& Fauziah Fitri Ella (2006). Analisis Pengaruh Keunggulan Produk, Kegunaan Produk Dan Promosi Terhadap Tingkat Kesuksesan Produk Telkom Flexi Di Jepara. Jurnal Dinamika Ekonomi \& Bisnis. 3(2). pp: 155-173.

Kotler, Philip \& K.L. Keller (2012). Manajemen Pemasaran. Edisi 13. Jilid 2. Erlangga. Jakarta.

Kotler, Phillip (2009). Manajemen Pemasaran, Edisi 13. Jakarta; Erlangga.

Krisna Hadi, Ryan (2013). Pengaruh Keunggulan Produk Terhadap Minat Beli Ulang Konsumen Pada Produk Rangka Atap Baja Ringan Taso C75.75. Jurnal Sains Pemasaran Indonesia. 12(3). Pp: 346-356.

Kristiana \& Wahyudin (2012). Pengaruh Persepsi Atribut Produk Terhadap Minat Beli Ulang Konsumen (Study Pada PT. Karya Zirang Utama Isuzu Semarang). Jurnal Ilmu Manajemen, Volume 3 Nomor 1.

Kurniawan, dkk (2008). Analisis Faktor-Faktor yang Mempengaruhi Minat Beli Ulang Produk serta Dampaknya terhadap Loyalitas Pelanggan (Studi Kasus pada Produk Sakatonik Liver di Kota Semarang).

Kurniawan, I., Santoso, S. B., \& Munas, D. (2007). Analisis faktor-faktor yang mempengaruhi minat beli ulang produk serta dampaknya terhadap loyalitas pelanggan. Jurnal Studi Manajemen \& Organisasi, 4(2), 27-42.

Navarone, Okki (2003). Analisis Pengaruh Tingkat Kesuksesan Produk Baru dalam Peningkatan Minat beli. Jurnal Sains Pemasaran Indonesia. 2(1). Pp: 111122.

Nusarika, L., \& Purnami, N. (2015). Pengaruh Persepsi Harga, Kepercayaan, Dan Orientasi Belanja Terhadap Niat Beli Secara Online (Studi Pada Produk Fashion Online Di Kota Denpasar). E-Jurnal Manajemen Universitas Udayana, 4(8), 254393.

Pujadi, Bambang (2010). Pengaruh Citra Merek Terhadap Minat Beli Melalui Sikap Terhadap Merek, Semarang: Universitas Diponegoro.

Purba, J.R (2011). Pengaruh Keunggulan Bersaing Dalam Perumusan Strategi Pemasaran Terhadap Citra Merek Pada Rumah Makan Wong Solo Medan, Universitas Sumatera Utara, Medan.

Rimiyati, H., \& Widodo, C. (2014). Pengaruh Citra Merek, Kualitas Produk, Kepuasan Konsumen Terhadap Loyalitas Konsumen Merek Samsung Galaxy Series (Studi Pada Mahasiswa Universitas Muhammadiyah YOGYAKARTA). Jurnal Manajemen Bisnis, 5(2), 223-234. 
Saidani, Basrah dan Arifin, Samsul (2013). Pengaruh Kualitas Produk dan Kualitas Layanan terhadap Kepuasan Konsumen dan Minat Beli Ulang Ranch Market. Jurnal Riset Pemasaran Sains Indonesia (JRMSI), Vol. 3, No.1.

Surya Ningrum, Lily \& Nurcahya, I Ketut (2014). Pengaruh Pelaksanaan Program Corporate Social Responsibility (CSR) Terhadap Corporate Image dan Perilaku Word-of-Mounth (WOM) pada PT. Sidomuncul. E-Jurnal Manajemen Universitas Udayana. 3(3). Pp: 2302-8912.

Tariq et al., (2013). Customer Perception About Branding And Purchase Intention: A Study of Fincgin An Emerging Market. Journal of Basic and Applied Scientific Research, 3(2), 340-347.

Thamrin, M., Novita, D., \& Sari, D. A. (2018). April 2018 Volume 01 No 02. Journal of Agribusiness Science, 01(02), 90-100.

Tjiptono, F., \& Diana, A (2016). Pemasaran Esensi dan Aplikasi. Yogyakarta: Andi.

Tripratiwi, D., Minarsih, M. M., \& Hasiolan, L. B. (2016). Analisis Pengaruh Harga , Keunggulan Produk Dan Citra Merek Terhadap Minat Konsumen Dalam Pembelian Mobil Mitsubishi Sport Pada PT Bumen Redja Abadi Semarang. Jurnal of Management, 2(2). https://jurnal.unpand.ac.id/index.php/MS/article/view/570

Uniqlo.com (2018). Dari Tokyo ke Denpasar Uniqlo: https://www.uniqlo.com/id/corp/.

Voss, G.B. \& Zannie, G.V (2000). Strategic Orientation and Firm Performance in an Artistic Enviroment. Journal of Marketing.

Wang, Hui-Ya. \& Tsai, Chi-Fen (2014). The Relationship Between Brand image and Purchase Intention: Evidence From Award Winning Mutual Funds. The International Journal of Business and Finance Research. 8(2), Pp: 27-40.

Wahid, M. A (2016). Analisis Pengaruh Kualitas Produk Terhadap Keputusan Pembelian Melalui Citra Merek dan Nilai Pelanggan (Studi Pada Pengguna Motor Matik Suzuki NEX FI).

Waldi, Drajat Adhitya \& Purbayu Budi Santosa (2011). Analisis Pengaruh Atribut Produk \& Promosi terhadap Persepsi Keunggulan Produk Motor Merek Milenium (Produk Motor China), Jurnal Strategi Bisnis, Vol. 6 Th. IV.

Wijaya, T. (2015). No Title. Pengaruh Service Quality Perception Dan Satisfaction Terhadap Repurchase Intention.

Woran Nita, Tumbel Altje, R. P. Van. (2016). Pengaruh Customer Relationship Marketing, Nilai, Keunggulan Produk dan Kepuasan terhadap Loyalitas Nasabah (Studi pada Bank Mega Jl. Piere Tendean Mega Mall Manado). Jurnal Berkala Ilmiah Efisiensi, Vol 16, No(01), 771-782.

Yusmawan, Suharyono, Kumadji, dan Rahardjo (2014). "Journal Of The Effect Of The Product Quality Mediation And Brand Image On The Influence Of 
E-Jurnal Manajemen, Vol. 10, No. 3, $2021: 229-249$

Pricing Policy And Service Quality Towards Trust", Journal Of Contemporary Research In Business, Vol. 5, No. 9, Malang: Universitas Brawijaya Malang.

Zeithaml, Valari A. and Mary Jo Bitner (2000). Service Marketing, New York, Mc.Ggraw-Hill Co. Inc. 